\title{
Silicon Valley, Women, and the California Dream
}

\author{
G E N DER, CLAS S, A N D O P P ORT U N T Y \\ I N THE TW E N T I E TH C E N T U R Y
}

Glenna Matthews

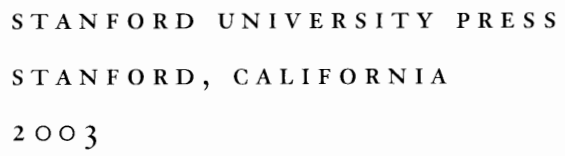




\section{Stanford University Press \\ Stanford, California}

(C) 2003 by the Board of Trustees of the Leland Stanford Junior University

Published with the assistance of the Edgar M. Kahn Memorial Fund.

All rights reserved.

Library of Congress Cataloging-in-Publication Data

Matthews, Glenna.

Silicon valley, women, and the California dream : gender, class, and opportunity in the twentieth century / Glenna Matthews.

p. $\mathrm{cm}$.

Originated as the author's doctoral thesis, Stanford University, I977. Includes bibliographical references and index.

ISBN 0-8047-4 I 54-9 (cloth : alk. paper)

ISBN 0-8047-4796-2 (paper : alk. paper)

I. Women computer industry employees - California - Santa

Clara Valley. I. Title: Gender, class, and opportunity in the twentieth century. II. Title.

$$
\begin{aligned}
& \text { HD6O73.c65222 U56 } 2003 \\
& 33 \text { I.4'8I004'0979473-- dc2 I }
\end{aligned}
$$

2002004728

Designed by Janet Wood

Typeset by BookMatters in $10 / \mathrm{r}_{4}$ Janson

Original Printing 2002

Last figure below indicates year of this printing:
I 2
I IO 0908
$0706 \quad 05$
$\begin{array}{lll}\mathrm{O}_{4} & \mathrm{O} 3 & \mathrm{O} 2\end{array}$ 
To my dear friends Monica Loewi, Sandy Maboney, and John Snetsinger In memory of Larry Maboney 
